\title{
The Influence of the Neoconservative Movement on U.S. Foreign Policy
}

\author{
Arsenije Dusanic and Plamen P. Penev *
}

This brief essay is drawn from a larger dissertation project at the University of Vienna dealing with the subject of neoconservatism, written under the supervision of Prof. Heinz Gärtner. In the limited space available here, we will primarily attempt to explain a few small facets of this political-philosophical phenomenon. We will also make an effort to illuminate the pattern of explanations offered for the military deployment in Iraq, which was vigorously promoted by neoconservatives in the United States. Who are the Neocons actually? What are their goals? What beliefs and experiences shape their thinking?

The term neoconservative has never represented a coherent and unified political construct; there was no central link between the various political ideas that characterize the positions held by those thinkers typically identified with neoconservatism. The centrifugal forces within the neoconservative community have typically been predominant, until the movement is mobilized by the awareness of an enemy. This is most notably the case in the original animating impetus behind the emergence of neoconservatism in the U.S.: anti-communism and the pursuit of victory over the Soviets. Most histories of the movement trace its origin to a group of formerly leftist thinkers in the U.S. who in the middle of the twentieth century were driven rightward by the totalitarian excesses of Stalinism in the USSR. Almost all scholars who have studied the issue speak of a loose grouping of liberal intellectuals who share similar ideas and views and who mainly use publications in magazines (The Public Interest, The National Review, Commentary, and The Weekly Standard) to advance their thinking and disseminate their ideas. Martin Lipset summed up this view of the diverse and fragmented nature of the movement, stating that the perception of the neoconservatives as a tightly unified group is based on a phenomenon that most sociologists call "labeling."

Neo-conservatism, both as an ideological term and as a political grouping, is one of the most misunderstood concepts in the contemporary political lexicon. The reason is simple: the word has never referred to a set of doctrines to which a given group of adherents subscribed. Rather, it was invented as an invidious label to undermine political opponents, most of whom have been unhappy with being described as "neoconservative." The neoconservatives are perhaps the most prolific group of intellectuals in

Arsenije Dusanic was educated in Belgrade and Moscow. He has also studied in Vienna, Hong Kong, and Buenos Aires. He holds an MSc in Economics from the Vienna University of Economics and Business Administration, and will be studying at the London School of Economics in the following academic year. Plamen P. Penev studied political science at the Free University of Berlin, and received his $\mathrm{Ph} . \mathrm{D}$. in political science from the University of Vienna in 2008. 
American history; in fact, neoconservative thought on practically every major issue of U.S. politics or policy in the past forty years is extensively developed.

Francis Fukuyama adds that the neoconservatives have an idealistic belief in social progress and the universality of rights, coupled with intense anti-communism. And it is remarkable that main principles of neoconservatism feature no coherent vision in relation to the domestic and foreign affairs in the United States, with only one exceptionthe fight against the USSR.

One can argue that, without the Cold War, neoconservatism could not exist. Just as the events of 11 September 2001 provided the "window of opportunity" for contemporary neoconservatives to implement their agenda in Iraq, the Cold War played the same role for neoconservatives fifty years ago. Hence, our first hypothesis is that the Cold War assured the existence of the neoconservative movement. The provocative question raised by this hypothesis is its opposite implication: Why didn't neoconservatism disappear with the end of the Cold War? Instead, the movement lurked for a while behind the liberal internationalism of the Clinton era, particularly given that President Clinton was also willing to approve the use of military resources for humanitarian missions. However, after their years of semi-exile during the Clinton Administration, U.S. Neocons successfully and artfully invented the doctrine of morally-motivated interventionism, which they planned to use to overturn the old order of the international peace architecture.

To discuss neoconservatism as a complex set of ideas is accurate and apt, since the neoconservative legacy is complex and heterogeneous. We can distinguish between a few generations and typologies of neoconservatives: Cold War liberals, democratic internationalists, liberal imperialists, realistic Wilsonians, Straussians, neoconservative realists, liberal realists, etc.

After September 11, and especially after the Iraq War, many commentators explored the intellectual links between the neoconservative movement and Leo Strauss, a European émigré and longtime political philosopher at the University of Chicago who died in 1973. What is remarkable about these writers' obsession with the Strauss connection is that Leo Strauss never held an opinion on Saddam Hussein or Iraq. In fact, Leo Strauss had been dead for three decades by the time contemporary Neocons became preoccupied with regime change in Iraq. Thus, we cannot find a significant intellectual debt to Strauss in contemporary neoconservatism. ${ }^{1}$ Strauss's writings, in short, are philosophical inquiries and have nothing of the dogma of a political movement. His thought culminates in no political program, no slogans or "cookie cutter" approaches to public policy. His focus is on how to read the so-called "Great Books." Strauss was characterized by many of his critics as the intellectual mastermind behind the war in Iraq, as an elitist who preached a policy of force and deception, and as the philosopher-king of the neoconservative movement.

The creed of Leo Strauss might be reduced to six principles: a deep suspicion of the power of the state; a preference for liberty over equality; patriotism; a belief in established institutions and hierarchies; skepticism about the idea of progress; and elitism. 
One of the most widely quoted definitions of the movement identifies neoconservatives as conservative internationalists with idealistic-utopian aspirations (in the vein of Lenin and Trotsky), who endorse high military spending and define the United States' national interest very broadly. What they feared most was global anarchy, in the terms of the neo-realist school in international relations (similar to that articulated by Hans Morgenthau and Kenneth Waltz), in which evil conquers good. In terms of the structure of U.S. government, they desired an "imperial presidency" (in the words of Arthur Schlesinger); thus, neoconservative intellectuals were active under various presidents, based on the so-called "revolving door principle."

Francis Fukuyama, writing in the period after his detachment from the neoconservative movement, explained that neoconservatism today has become evidently associated with concepts like coercive regime change, unilateralism, and American hegemony and primacy (the set of ideas that has come to be known as the Bush Doctrine). But the attempt to examine neoconservatism only in the context of the policies of the Bush Administration is too simplistic, and does not offer sufficient guidance for interpreting neoconservatives' political-philosophical concepts. Rather, what is needed is an intensive investigation of U.S. foreign policy since Woodrow Wilson, which even found resonance as recently as the 2008 presidential election in the United States. The contemporary neoconservative agenda is about shaping a new kind of politics, where the instruments of hard power lie in the foreground, while soft power-which actually won the Cold War (as Margaret Thatcher noted, Ronald Reagan won the Cold War without firing a shot) - will be maneuvered onto the sidelines.

The moral and historical error of the neoconservatives lies in their own narrowmindedness, as most critics point out. Two widely noted works of political sciencethe first by Francis Fukuyama (The End of History, published in 1992) and the second by Samuel P. Huntington (The Clash of Civilizations, published in 1996) — have had an enormous impact on the philosophical and dialectical thinking of contemporary neoconservatives. ${ }^{2}$ These two books have to a certain extent transformed the thinking of the neoconservative movement, and brought the Neocons to the conclusion that democracy is the primary achievement of humanity and now, since the Cold War has ended, it is the task of the modern Western democracies, especially the United States, to spread democracy throughout the world. Such ideas - which were also expressed by political dissidents such as Natan Sharansky_were the basis for a historically congenial version of the global political map after the Cold War.

Along with Francis Fukuyama, another author whose ideas were kidnapped by the neoconservatives was Samuel P. Huntington. First in an article in Foreign Affairs and then in his book-length study The Clash of Civilizations, he explained his thinking about the future of international relations. What Huntington wanted to say was certainly not what most neoconservative intellectuals wanted to hear. Following Oswald Spengler and Arnold Toynbee-whose most influential books were published before

2 Francis Fukuyama, The End of History and the Last Man (New York: Free Press, 1992); and Samuel P. Huntington, The Clash of Civilizations and the Remaking of World Order (New York: Simon \& Schuster, 1996). 
World War I and after World War II, respectively—-he analyzed the relationships between different cultures (an interaction he famously characterized as the "clash of civilizations"). The ideological narrative of the second generation of neoconservatives combined the views of Huntington and Fukuyama. From then on, the leitmotifs in the scholastic world of contemporary neoconservatives were dogmatic activism and historical determinism, which nobody in "Old Europe" wanted to understand. It is this ideological basis that constitutes the now rigid structure of indoctrination for the neoconservative movement, since with the passing of Fukuyama and Huntington they lost two of the most prominent political scientists of the twentieth century.

The dream that democracy is the inevitable fate of humanity and the belief that the "clash of civilizations" is looming over the horizon-with an implacably hostile Islam as the main actor - resulted in a Manichaean doctrine, which neither of the two abovementioned scholars would have accepted. Democracy as a terminus of human development on the one hand, and the existential struggle with the moral values of Islam on the other, was the foundation of the neoconservative mindset, which suddenly gained a philosophical character.

Even Fukuyama himself stressed that many readers had misunderstood his book The End of History and the Last Man. If neoconservatives wanted to know what the yearning for democracy is, they should have read Fareed Zakaria's The Future of Freedom. ${ }^{3}$ That all people aspire for freedom is self-evident; Immanuel Kant postulated it in his categorical imperative in the eighteenth century. But the notion that Western liberal democracy offers the appropriate recipe for the reconstruction of societies, regardless of culture, is not necessarily true. For Fukuyama, everything was primarily about modernization. What was universal from the beginning was not a dream of a liberal democracy, but the desire to live in a post-modern society, with its technical achievements, high standard of living, and quality health care. ${ }^{4}$ However, the neoconservative apologists could not know this, since ultimately they never dealt with such issues (e.g., social engineering, nation building) in their programmatic agendas.

It is important to take a step back from the many imprecise conclusions of many journalistic sources and try to conduct an in-depth analysis of the issues. In doing this we will try to retain a scientific approach and remain (reasonably) close to neutral in our views. The risk of failing while verifying or falsifying the hypothesis is always present; nonetheless, we will attempt to tackle the problem scientifically.

Today, neoconservatism is very often associated solely with the U.S. military interventions in Afghanistan and Iraq, which is only partially true. What many critical observers often forget is that neoconservatism is not a simple term of definition, and to present neoconservatism only with the help of simple comparisons and conspiracy theories would bring us to a deadlock.

3 Fareed Zakaria, The Future of Freedom: Illiberal Democracy at Home and Abroad (New York: W.W. Norton, 2003).

4 See Robert Cooper, The Breaking of Nations: Order and Chaos in the Twenty-first Century (London: Atlantic Books, 2003). 
We ourselves do not purport to be apologists for neoconservatism, but we do think that it represents one of the possible sets of strategies in the fight against terrorism. It does not mean that "the Neoconservative Moment" must necessarily transform into a "unipolar moment." Furthermore, it is clear that neoconservatism does not represent the only possible political-philosophical world order. Contemporary neoconservatism is "a kind of muscular Wilsonianism, minus international institutions."

So, was the U.S. attack on Iraq legitimate and legal? From the neoconservative point of view, it definitely was. According to the neoconservative point of view, military action was justified because Saddam Hussein had long been considered to be a disruptive factor in the region. Involved in both Gulf Wars (against Iran and then the invasion of Kuwait), Saddam was ready to risk a "World War IV" and to assume the role of a peer (and competitor) to the U.S. ${ }^{7}$

From the neoconservative perspective, Saddam was far more dangerous to the United States than Al Qaeda. This could be seen in the attempts by three key members of the administration of the second President Bush-Under Secretary of Defense Douglas Feith, Deputy Secretary of Defense Paul Wolfowitz, and Secretary of Defense Donald Rumsfeld - to convince the president that Iraq represented a crucial issue for U.S. security. The nightmare scenario that had Saddam secretly developing a functional WMD program caused suspicion that terrorist organizations such as Al Qaeda could gain possession of such deadly weapons, which in turn led to the conviction that the security of the American people and the territorial integrity of the American nation were at stake. This was a rational argument, and the Iraqi leadership bore some responsibility for feeding this key tenet of neoconservative belief, because Saddam and his clique broke several international agreements, and evicted UN weapons inspectors from the country. Furthermore, the Hussein regime was willing to cooperate only when placed under pressure from the U.S. and UN; even so, however, it obstructed inspections and never disclosed the extent of its "nuclear program." In the end, the neoconservatives were suspicious, and could not view the efforts (and perhaps the honest intentions) of the Iraqi dictator as being serious and credible.

Saddam himself also made a miscalculation, and showed that he had not learned much from the first Gulf War. When he intervened in Kuwait, Saddam was convinced that he would be able to dictate his conditions to the international community, led by the United States. It was true that the American position irritated him, since the U.S. administration $a$ priori had ruled a military invasion of Kuwait by Iraq as being unacceptable. So he calculated that - in spite of its clearly articulated position - the United States would swallow the strategic defeat represented by his invasion of Kuwait and negotiate with him. This gross underestimation cost the Iraqi dictator significant domestic and international legitimacy, and negated his reputation in the Middle East as a

Charles Krauthammer, "The Unipolar Moment," Foreign Affairs (Winter 1990-91).

6 Francis Fukuyama, America at the Crossroads: Democracy, Power, and the Neoconservative Legacy (New Haven: Yale University Press, 2007).

7 See Norman Podhoretz, World War IV: The Long Struggle Against Islamofascism (New York: Doubleday, 2007). 
promoter of pan-Arab unity. Saddam wanted to be the new Nasser, but ultimately he came to be seen as a villain who attempted to thumb his nose at the world's sole superpower, and to change the geopolitical order in the world's most sensitive region.

President George H.W. Bush's response at this time was deliberate and well thought-out. U.S. Secretary of State James Baker and National Security Advisor Brent Scowcroft assembled an international military coalition, which was also supported by the UN, and which forced Saddam to retreat. There was, however, no UN mandate to depose Saddam, and he remained in power, although with significantly diminished credibility, even within the Arab world.

Saddam's original blunder was that in September 1980 he had believed that the entire Arab world would support him after he ordered his troops to attack Iran. Obviously, this war was sparked by a territorial conflict between the two countries, but the idea that the Iraqi despot represented the Arab cause against the Persians carried a double flaw. This war-which Saddam deliberately orchestrated, and was the longest and most intense war fought since 1945-represented a risk factor for the Saudi regime, and did not help either of the adversaries to achieve its political goals.

An additional significant neoconservative argument in favor of U.S. intervention in Iraq was rooted in the belief that the United States had to show the United States' potential adversaries and enemies in the Middle East that the new Bush Administration was prepared to act swiftly and firmly, with a full mobilization of U.S. political, economic, and social resources (as compared with the Clinton Administration's indecision). According to this line of argument, it would be a tremendous mistake to give terrorists evidence to support the belief that the United States would pull back from one of the regions of greatest strategic importance for its national interests (the Middle East) simply because it had been hit hard by a terrorist attack on 9/11. Terrorist groups needed to know that the new American leaders would make no distinction between terrorists and their supporters. An American retreat from the Middle East would be equivalent to admitting defeat; thus, the U.S. response to attacks of this sort had to be prompt and supported by overwhelming military strength. Even though the Cold War was long since over (and was in no danger of reheating), the old tried and tested notions of the Cold War era such as the domino theory gained renewed importance. Should the U.S. lose in Iraq, this would have unforeseeable consequences for the entire Middle East - this was the main premise of many neoconservative proponents, like Richard N. Perle and Elliott Abrams.

U.S. neoconservatives also saw the occupation of Iraq as the next step in the larger reconstruction of the entire Middle East. They tried to present their ideas to the world community as a plan for the "Greater Middle East." "However, this plan existed only on paper, and was never implemented. The neoconservatives developed this plan- the

8 See "A Clean Break: New Strategy for Securing the Realm," report prepared by the Institute for Advanced Strategic and Political Studies' "Study Group on a New Israeli Strategy Toward 2000." The main substantive ideas in this paper emerged from a discussion in which prominent opinion makers - including Richard Perle, James Colbert, Charles Fairbanks, Jr., Douglas Feith, Robert Loewenberg, David Wurmser, and Meyrav Wurmser-participated. 
so-called "Road Map" - and tried to impose it on their Israeli partners (such as Benjamin Netanyahu and Ariel Sharon) as well as the Palestinians. The plan failed miserably, however, as the "Greater Middle East" notion in their presentation received no support from either the Israelis or the Palestinians. Neoconservative attempts to reshape the geopolitical landscape, enhance the level of regional and global security, and make Iraq a model democracy for the entire Arab world were extremely ambitious; however, they lacked any significant awareness of (and accounting for) cultural and historical realities.

Analogies between the wave of democratization after World War II in West Germany, Italy, and Japan with the situation in an ethnically and religiously heterogeneous tribal state showed how deeply flawed the neoconservative argument actually was. Iraq was envisioned as being the first democratic Arab state, and was assigned the task of weakening both pan-Arabism and Islamist radicalism; it will be a long time before this neoconservative project comes to fruition (if it is ever achieved at all). It became increasingly unrealistic to talk about the rise of democratic institutions, economic progress, and social emancipation in Iraq (which is not to say that this neoconservative idea was by definition impossible - exactly at the time this article was being written, shortly before the U.S. elections in November 2008, it seemed that some progress was being made with regard to security and stability in Iraq).

Another key argument of neoconservative foreign policy-the democratization premise - had a humanitarian dimension that some critics grossly underestimated. According to this view, one of the main reasons for the U.S. deployment in Iraq was the question of universal human rights (the U.S. violations of human rights at Guantanamo and Abu Ghraib represent dark spots in this regard). Saddam was a cruel dictator who used his Baath regime to create a terrorist state based on repressive and barbaric means of control, and the neoconservatives wanted to put an end to this. The parallels to Woodrow Wilson's agenda and his appeal of "making the world safe for democracy" are easy to recognize. What strengthened the new neoconservative belief in the humanitarian dimension of U.S. foreign policy was the hypothesis that such a brutal regime - with its apparatus of state power and patronage structures for pitting groups against each other-could be replaced with a moderate leadership. Freedom and democracy are "God's gift to humanity," as George W. Bush said, and the neoconservatives saw themselves as leading the United States down the right path, however difficult (and the end of which is yet not in sight). From the perspective of many political observers, the scope of the neoconservative blunder in the Middle East does not necessarily seem as irreparable today as it did three years ago. So there remains the hope that the new U.S. leadership under President Obama will bring changes to the U.S. blueprint for a democratic and more territorially stable Middle East.

The second intervention in Iraq emerged in the post-Cold War era, and many of the United States' traditional partners believed that the American "benevolent hegemon" was now disoriented, and in search of new arenas of geopolitical conflict and control. The unprecedented level of unipolarity after the collapse of the Soviet Union allowed U.S. forces free rein to intervene anywhere and anytime they wanted. A number of leftoriented critics of the neoconservative school—such as Immanuel Wallerstein, Em- 
manuel Todd, and Noam Chomsky - discussed the thesis that U.S. foreign policy had lost its compass in the wake of the Cold War and the proxy wars in the Third World, and could not find a substitute for its lost spheres of influence in Vietnam and Iran. The geopolitical tide in the Persian Gulf had shifted dramatically against the United States, and a new guarantor of stability (and promoter of U.S. interests in the region) was needed.

It is hard to imagine that the neoconservatives wanted to promote Iraq as their primary mechanism of domination and control in the region, and reduce their dependence on the Saudi royal family. But it is indisputably true that the United States relocated their naval formations in the Persian Gulf, in the process providing a tremendous number of new bases from which to launch air operations, so that even Turkey's refusal to allow U.S. troops to use its territory (and thus open a new front in the Iraq war) did not prevent the U.S. from dislocating Iraqi forces. So the criticism promoted by opponents of the neoconservatives that the U.S. invaded Iraq in order to improve its own strategic and military position is simply not relevant. Even the presumption that the United States was actively searching for war scenarios in the Middle East, and that the attacks of 9/11 provided a so-called "window of opportunity" are devoid of any logical basis.

Perhaps the most widely cited argument in favor of U.S. intervention in Iraq-one that is popular even today among many neoconservative intellectuals - is that the situation in the Middle East bore similarities to that in Europe in the 1930s. The analogy rests on the assumption that Neville Chamberlain's policy of appeasement toward the Third Reich essentially gave Germany permission to annex the Sudetenland. If Saddam is compared with Hitler (as many neoconservatives stated), George W. Bush could not follow the dangerous path set forth by the conservative British Prime Minister. According to neoconservatives, the United States will never again allow dictators to set the terms of negotiations, thus surrendering power to them and conferring legitimacy on their regimes. Had Chamberlain taken a tougher stance in 1938, this thinking holds, the world would have most likely avoided the Second World War.

The final element of the neoconservative interest in intervening in Iraq (one that is highly controversial) concerns the security of Israel. The political scientists John Mearsheimer and Stephen Walt argued in their book The Israel Lobby and U.S. Foreign Policy that the U.S. and the neoconservatives (a certain number of whom are of Jewish descent) had intervened in Iraq in order to guarantee the security and borders of Israel. ${ }^{9}$ This absurd thesis simply cannot be true, because Iraq had lost its monopoly on weapons procurement after the first Gulf War, and was not capable of posing a serious threat to the Israeli Defense Forces, which are superbly trained and equipped with the most modern armaments. The international sanctions and arms control measures in the wake of Iraq's failed annexation of Kuwait in the 1990s nullified Iraq's military poten-

9 See John J. Mearsheimer and Stephen M. Walt, The Israel Lobby and U.S. Foreign Policy (New York: Farrar, Straus, and Giroux, 2007). Our argument here draws on Max Boot's essay, "Myths About Neoconservatism," in Neoconservatism, Irwin Stelzer, ed. (London: Atlantic Books, 2004), 45-52. 
tial, so it was extremely difficult for Saddam even to maintain the miserable state of its army, much less to speak about upgrading it.

The argument of this article is that neoconservatism as it applies to U.S. foreign policy has a liberal vision; its roots lie in a bygone landscape, at the dawn of America's struggle against a totalitarian foe. At home and abroad, the struggle for democracy is also a struggle for equal opportunity. For many neoconservatives, liberty alone is the goal, and government action to promote social justice imperils it. But for modern liberals like Peter Beinhart, championing freedom around the world requires championing development, because (as the architects of the Marshall Plan understood) liberty is unlikely to survive in the midst of economic despair and social engineering. ${ }^{10}$

The Neocons supported the war because they considered it the only remaining way to prevent Saddam Hussein from obtaining a nuclear bomb. They also believed it could produce a decent, pluralistic Iraqi regime, which might help open a democratic "third way" in the Middle East between secular autocrats and their theocratic opponents-a third way that offered the best long-term hope for protecting the United States' strategic interests. The blunders in Iraq will haunt U.S foreign policy for years to come, but the war on terror will likely last even longer that that. How the United States fight it will help shape the kind of country it becomes in the new millennium.

${ }^{10}$ See Peter Beinart, The Good Fight (New York: HarperCollins, 2006). 


\section{Bibliography}

A Clean Break: New Strategy for Securing the Realm In Study Group on a New Israeli Strategy Toward . Institute for Advanced Strategic and Political Studies, 2000.

Beinart, Peter. The Good Fight. New York: HarperCollins, 2006.

Boot, Max. "Myths About Neoconservatism." In Neoconservatism, 45-52. London: Atlantic Books, 2004.

Cooper, Robert. The Breaking of Nations: Order and Chaos in the Twenty-first Century. London: Atlantic Books, 2003.

Fukuyama, Francis. America at the Crossroads: Democracy, Power, and the Neoconservative Legacy. New Haven: Yale University Press, 2007.

Fukuyama, Francis. The End of History and the Last Man., 1992.

Huntington, Samuel. The Clash of Civilizations and the Remaking of World Order. New York: Simon and Shuster, 1996.

Krauthammer, Charles. "The Unipolar Moment." Foreign Affairs 70, no. 1 (1991).

Mearsheimer, John J., and Stephen M. Walt. The Israel Lobby and U.S. Foreign Policy. New York: Farrar, Straus, and Giroux, 2007.

Podhoretz, Norman. World War IV: The Long Struggle Against Islamofascism. New York: Doubleday, 2007.

Zakaria, Fareed. The Future of Freedom: Illiberal Democracy at Home and Abroad. New York: W.W.: Norton, 2003. 